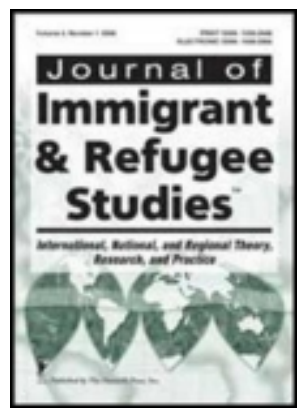

\title{
Leaving Europe: new crises, entrenched inequalities and alternative routes of social mobility
}

\begin{tabular}{|c|l|}
\hline Journal: & Journal of Immigrant \& Refugee Studies \\
\hline Manuscript ID & WIMM-2019-0178.R1 \\
\hline Keywords: & $\begin{array}{l}\text { Europeans Abroad, Expatriates, Social Mobility, Inequality, Onward } \\
\text { migration }\end{array}$ \\
\hline Abstract: & $\begin{array}{l}\text { This article addresses conceptual issues around contemporary forms of } \\
\text { out-of-Europe migrations of various European publics. In particular, we } \\
\text { ask how such moves contribute to both the decentring of Europe in } \\
\text { migration debates, and to the 'de-migranticization' (Dahinden 2016) of } \\
\text { the social scientific study of migration. This article also serve as } \\
\text { introduction to this special issue entitled "Leaving Europe: Alternative } \\
\text { routes of up/outward mobility" and which aims to document } \\
\text { ethnographically new forms of European emigration and shed light on an } \\
\text { imaginary of Europe which is not conceived as a place of prosperity and } \\
\text { success but rather as a locus of disempowerment. }\end{array}$ \\
\hline
\end{tabular}

\section{SCHOLARONE" Manuscripts}




\title{
Leaving Europe: new crises, entrenched inequalities and alternative routes of social mobility
}

\author{
Karel Arnaut, Jean-Michel Lafleur, Nadia Fadil, Jérémy Mandin, \& Jaafar Alloul \\ Introduction
}

This special issue tries to map, describe, and understand the aspirations and strategies, the hopes and anxieties of people leaving behind Europe in order to settle, work, and live in other parts of the world - while some do not consider a future return to Europe as a desired option. Such out-ofEurope resoluteness appears to be in complex ways related to a sense of crisis which the people under consideration experience and seek to defy. The 'crisis' felt at work in the lives of these mobile Europeans can best be identified as "a crisis in and of Europe" (De Genova and Tazzioli 2016) in which, according to Sarah Green (2013:345) the 2008 financial and the ensuing economic crisis was merely "one in a series of events to have occurred in recent decades" as a result of which "the position of Europe, as a place and as an idea, has been undergoing considerable relocation".

'Relocation' is one of the central themes animating this special issue, resonating with Europe's postcolonial repositioning and reinvention, deeply connected with (a) intensifying debates about its historical privileges, or alternatively its potential provincialisation which are often translated in (b) struggles over internal and external borders - again, both physical and legal. These debates and struggles are informed by (c) key issues of redistribution, inequality and racialization which are entrenched in the long durée of colonial and postcolonial history. Taken together, in late capitalist Europe which the people featuring in the case studies of this special issue, are leaving behind, "the cards of labor, mobility and sovereignty are mixed and redistributed again" (Papadopoulos and Tsianos 2013:179).

The people under consideration in this special issue are not only keen observers of the transformation of Europe; they are also actors in this process. Two immigrant profiles appear in this volume that question our representation of Europe and European migration. On the one hand, there are individuals whom, through their forebears, have a so-called migration background such as the Somali and Maghrebi emigrants discussed by Scharrer, as well as Mandin and Alloul. On the other hand, far from the cliché of the "expatriate", we find other migrants such as the European graduates who find themselves competing for jobs with Asian labor migrants in Tokyo and Singapore (discussed by Hof) or being illegalized and pejoratively labelled such as the new Spanish immigrants arriving in Rio de Janeiro reported by Heil. In sum, the migratory moves out of Europe we document here illustrate how status of Europe and Europeans in global post-colonial histories are being contested.

What the different articles in this volume reveal is that the thematic focus on 'leaving Europe' does not merely serve to document lesser known migratory directionality, it also invites readers to adjust their methodological approaches to both decenter Europe, and 'de-migranticize' the study of migration. 


\section{Decentering Europe in a polycentric world of complex migration movements}

While it tends not to acknowledge itself as such, Europe is a traditional place of departure for emigrants, and citizens of European nation states have historically populated different parts of the world in relation to colonial expansion or political and economic difficulties faced repeatedly by the continent. In the $19^{\text {th }}$ century alone, historians estimate that between 46 and 62 million individuals left Europe for another continent (Gould 1979, see also: Mintz 1998). However, as noted by historians, compared to contemporary immigration to Europe, traditional emigration out of Europe has not always been documented carefully. Similarly, we tend to overlook the fact that while people of European origin represent a large segment of the population in different states in the Americas and Oceania, a significant number of European migrants returned to Europe after an experience overseas (Luconi 2006) - something which does not appear to be on the agenda of the European emigrants featuring in this special issue.

With few exceptions, social sciences scholarship has not paid much attention to contemporary forms of European emigration. Western Europe has traditionally starred as a major (colonial) center of economic, political and cultural influence in the world, and thus as a core destination for all sorts of immigrant and capital flows. When European emigration is addressed, it is often through the image of the privileged 'expat' (Fechter and Walsh 2010). While some historical work has been done on 'troubled' publics within colonial migration currents from Europe to the 'New World' or to the other colonies (Oxley 1996), less frequent are more contemporary studies on mobile pathways of subaltern 'success' (Reitz 1999) that apply a similarly global scope to human mobility. One of the central aims of this special issue is to de-center this view by ethnographically documenting imaginaries in which Europe is no longer conceived as a site of 'success' or 'prosperity', but as a location of disempowerment, deskilling and stigmatization.

Contemporary media representations and political discourses of immigration to Europe particularly in recent years - tend to stress the large-scale nature of the phenomenon. Moreover, they use ideologically charged terms such as "crisis" and "invasions" of immigrants proceeding from the Global South in order to legitimize urgent and exceptional measures taken to deal with increases in arrival of newcomers (Krzyżanowski, Triandafyllidou and Wodak 2018). In contrast, representations of European overseas migration continue to represent the phenomenon as individualistic and "exceptional" while insisting on social capital and skills of new European emigrants. Those depictions present us with two issues.

Firstly, contemporary narratives on mobility and migration are still largely premised on a center/periphery model which has been challenged by scholars for many decades now (See: Appadurai 1990:296). It not only overlooks the way international migration, today, is increasingly developing into a South-South movement, with $38 \%$ of all international migrants being born in a country of the less developed regions and moving in another developing country (compared to $35 \%$ for the South-North movement). ${ }^{1}$ The above mentioned representation also continues to abide by a series of racial slurs that depict brown and black bodies (i.e. the 'global south') as an invasive mass, largely driven by primary needs (food, shelter), versus highly individualized and 'explorative' mobile trajectories in the global North (Brown 2006, Hage 2017). Conversely, the 
different papers in this special issue show how the need for mobility is both existential and rooted in a new, increasingly polycentric, view on the world.

Secondly, these representations do not match the statistics of contemporary European emigration. In table 1 below, we can observe that the emigrant population proceeding from EU-28 Member States has grown significantly since 1990 but consists increasingly in intra-EU migration which more often than not is labelled as 'free movement' and not 'migration' - reserving the latter term for third country nationals. This data is unsurprising considering the political priority given to freedom of movement in Europe and the expansion of the EU towards Central and Eastern Europe, which has triggered intra-EU movements during this period. Yet, as it has been repeatedly documented, a share of these internal EU flows - and especially East-West and South-North movements - are frequently driven by similar socio-economic aspirations as the ones that push individuals to move from the Global South (Lafleur and Stanek 2017).

In spite of the increase in the regional character of EU citizens' emigration, the data below shows that, in absolute terms, the EU-28 emigrant population that moved to other continents than Europe is relatively stable in the last 30 -year period. In other words, while colonial expansion has ended and countries from the "New World" have long stopped actively recruiting European migrants, overseas European migration has not stopped. In addition, as shown in table 2, contemporary European emigration to other continents is not a phenomenon that affects exclusively Central and Eastern European Member States. Indeed, taken together, emigrants from large Western and Southern EU Member States (Germany, Spain, France, Italy, and the UK) have about half of their emigrant population residing outside of the European continent.

\section{[INSERT Table1]}

[INSERT Table2]

Overall, the above observations confirm that, contrary to its self-image and the deeply unequal representation of immigration to, and emigration from, Europe throughout the $21^{\text {st }}$ century, the old continent has continued to be both a place of immigration and emigration. 'Banalizing' migration in such a way allows the contributors to this special issue to reconsider this idea that Europe necessarily represents economic opportunities, civil liberties, and social mobility, which make it the ultimate goal in global migration. Instead, authors in this special issue observe how their interlocutors experience discrimination, exclusion, and misrecognition, within entrenched regimes of diversity and inequality either in Europe (see Alloul, Mandin, and Scharrer), in South America (Heil) or Asia (Hof) and directly related to European colonial presence in these parts of the world.

Moreover, decentering Europe for the mobile actors studied in this special issue results from a perceived quid pro quo between two considerations they hold prior to departure: their perception of how their capacities and identities are being recognized by others and their perception of the 
cities they settle in as alternative 'centers' in a newly polycentric world outside Europe. In this world where modernity is 'decomposed' into unequal status zones (see: Ferguson 2005) or where Europe is provincialized (Chakrabarty 2000) and generally "in crisis" (Gsir, Lafleur and Stanek 2016, King and Williams 2018, Ramos 2018), the authors here map and describe the moves of their mobile interlocutors in search of recognition and valorization of what they are capable of realizing elsewhere. In most general terms, the different contributors to this volume interpret their interlocutors' relocations in terms of transnational speculations and calculations that are projected valuations of their skills and identities, across different national or urban locations.

The youngsters of Maghrebi background in their twenties and thirties Alloul and Mandin engage with, claim they leave Europe desolately feeling sidelined by the society they grew up in: their training, skills and competencies are not valued (enough) in a way for them to envisage an auspicious future within Europe. The reason for this pessimism is that they feel not being judged in the light of what they can do but over who they 'are', identify as, or are seen to be: youngsters with a migrant background racialized as Muslims or people of color. The youngsters Alloul worked with opted for Dubai where they found a more open professional and social atmosphere albeit one that is driven by short-term contracts and the impossibility to obtain citizenship. Under these conditions, deliberations about, or planning of, future relocations is a daily concern. This is less the case among the youngsters Mandin studies and whose target destination is Montreal. Here the migration regime allows relatively easy access as tourists for people with EU passports and enables them to look for labor contracts which permit longer-term residence and leaving open the possibility for obtaining national citizenship. For both groups of Europeans in Montreal and Dubai, Europe has largely disappeared from the "horizon of expectation" (Cole 2014), unless things do not go according to plan. Indeed, whenever contracts end and residence permits expire, the gloomy prospect of illegalization, expulsion or forced return may put Europe on the map again.

The trajectories Scharrer describes are equally layered and multidirectional. The Somali families she worked with and who decided to leave Europe have a migration history behind them and relocate to Kenya in a movement that can be seen either as a return or as a secondary migration. While technically speaking it is secondary (or third etc.) migration, it is return in the sense of being closer to Somalia and to live in a society in which one is perceived less as stranger. In many cases, the new move is set up by parents who perceive their children as alienated from their ancestral culture and in need of a return to culture (dhaqan celin). This concern informs the choice of residence in city neighborhoods with an outspoken Somali presence (Somalinimo) and social infrastructure. For children and parents this relocation seems to work out quite differently. While the latter appear to anticipate a durable settlement in Kenya, the former often frame their reimmersion into Somaliness as temporary and look forward to making use of their EU passports to re-join Europe. Without wanting to make any predictions, it will be revealing to see if the Somali 'returnees' change their minds when entering the job market and perhaps experience what their parents did before or what the 'second generation' Maghrebi youngsters in Belgium and France were/are facing?

The trajectories of the young educated Europeans leaving Europe, labelled "Caucasian" by Hof, or the equally young and well-trained Spaniards (Heil), in search of job opportunities in Asian or 
South American world cities, respectively, appear less intricate than the ones presented so far. Conversely, Hof and Heil both demonstrate that the complexity rather resides in the emigrants' uncertain navigations of terrains in which Western and white privilege is challenged and destabilized. In the case of European youngsters in Singapore and Tokyo, this may unsettle their labor market position, while in the case of the Spaniards in Rio it may lead to illegalization and precarity.

\section{De-migranticization, recognition and transnational capital conversion}

This special issue examines in what sense the decision to leave Europe can be interpreted not only as a wish to take physical distance from Europe but also to take distance from what living in Europe represents for these new overseas migrants. The two are obviously related. By analyzing the directionality and the migrants' complex trajectories, the contributors explore the regimes of diversity and (social) mobility (Glick Schiller and Salazar 2013, Grillo 2010) at work in the places left behind or sought after by the migrants struggling with inequalities related to discrimination and stigmatization. This approach roughly falls in line with the recent calls to 'de-migranticize' (Dahinden 2016:2217) or demigrantize (Anderson 2019) the social scientific study of migration and situates itself in a longer strand of transnational studies focusing on migrants as agents of local/urban transformation (Çağlar 2016, Çağlar and Glick Schiller 2018). Following Dahinden's (2016: 2217) lead to "move away from treating the migrant population as the unit of [...] investigation and instead direct the focus on parts of the whole population, which obviously includes migrants", Anderson makes a convincing argument in favor of investigating "the workings of state-imposed categories of migrant and citizen in all their differentiations, their impacts on the experiences of individuals and groups, and the management, governance and accountability of national(ized) territories and international/global relations more generally." (Anderson 2019:6)

What makes this issue 'special' is that all contributions investigate the 'categories' Anderson mentions, but scrutinize these as part of national or local diversity regimes from the point of view of the migrants. In doing so, the different authors elicit the migrants' perception of how they are being labelled and positioned in the societies they straddle. These perceptions and experiences lend us an inside view of migrants' sense of how 'hope' (Hage 2003) or 'life chances' (Dahrendorf 1980) are unequally distributed in the places they leave behind and more advantageously meted out in the societies they are heading towards.

It could have been the obvious choice of our authors to fall back on Nancy Fraser's (2000) 'status model' of recognition and redistribution. This model could have supported their analyses of what migrants flee and seek with a combined reading of (a) misrecognition of "disesteemed groups" on the basis of their migrant background, religious profile, etc. - and (b) 'maldistribution' "which deprives actors of the resources needed for full participation" (ibid.: 117). Instead, and perhaps more appropriately for the phenomena at hand, almost all our contributors resort to Bourdieu's model of capital formation and conversion and connect with the post-2000 attempts to observe how such conversions play out across transnational borders and border regimes (Carruthers 2002, Erel 2010, Nieswand 2006, Weiss 2005). 
As part of a general theory of power struggles and societal domination, Bourdieu (1986) proposed a model distinguishing between three forms of capital - economic (money, property rights, etc.), cultural (education, skills) and social (networks, memberships) capital - which can be converted into each other according to established, say dominant conversion rates. This allowed Bourdieu to make sense of the dynamics or reproduction of social mobility by showing, for instance, how people with more economic capital could gain access to more prestigious schools and diplomas. These in turn allowed them to become part of privileged social networks and better paid jobs making this look like a 'natural' conversion of talents and skills into fair remuneration. The earliest applications of this model in migration studies readily valorize the analytical potential of Bourdieu's "differential rates of conversion of forms of capital" in bringing out the salience of one's societal position - or 'status' in Fraser's terminology - in negotiating rates of conversion. Carruthers (2002:427-28) for instance calls up gender position and migrant background, when referring to studies finding that young North American women receive less favorable rates of conversion of their economic, social, and cultural resources into educational gains than do young men, in order to document how "transmigrants" face "the same difficulty of interconversion" when moving "between national fields".

Likewise, following his earlier work on how Ghanaians face a 'status paradox' (loss of social esteem, gain of economic capital) while migrating to Germany, Nieswand (2014) makes use of Bourdieu's model of types of capital in order to tease out the intricacies of conversions of economic capital into social recognition when Ghanaian migrants return home. Often labelled 'Burgers', the returnees face a different paradox: On the one hand, Burgers can show proof of their acquired wealth, while on the other hand, their middleclass status lacks conventional legitimation, such as high education, prestigious occupation, and/or descent. Hence, Nieswand (2014:404) argues, "their appearance in the emigration areas of Ghana creates irritations to the established middle classes. Some of them are overtaken in terms of wealth by migrants who in respect to other status markers should be below them in the status hierarchy."

Another instance of applying Bourdieu's capital conversion framework to migrant careers - and one that is even closer to the cases in this special issue - is that of Polish entrepreneurs in Germany as analyzed by Nowicka (2013). She does not only look into how "various forms of capital are differently valued and given meaning in different contexts" but also "how migrants assess their own economic capital" (ibid.: 32). While describing cases of conversion from Germany (economic capital) to Poland (social or cultural capital) and the other way around, Nowicka (ibid.: 41) asks attention for ways in which "gender and ethnic origin" intersect with possibilities of capital conversions. Entrenched gender roles in both Poland and Germany deeply affect how women are capable of capitalizing on their skills and diplomas, Nowicka shows. Moreover, she explores how Poles in Germany explicitly assess their migrant careers in terms of the opportunities they were able to take, they missed or were unavailable to them. She also scrutinizes how this relates to the transnational spaces they direct their aspirations towards: more towards Poland or Germany or a combination of both. These aspirations, she concludes, are situated in the country where one's capital conversions are felt to me more successful. 
Several contributions to this special issue unpack similar complex assessments while engaging with the ways their interlocutors perceive, experience and renegotiate the (transnational) regimes of capital conversion they straddle. Like for instance the women in Nowicka's research, they are keenly aware that aspects of 'who they are' (woman, of a specific ethnic background in Poland) is as important as 'what they can' (cultural or education capital they possess). These valuations instantiate conversion grids not only for the different types of capital but also for the 'types' of people embodying, holding or, indeed, carrying them from one place to another.

In order to understand young Europeans entering the labor markets in highly industrialized Asian cities, Hof first of all considers the different resources - forms of capital - activated in deploying their transnational social mobility - e.g. social networks, foreign language proficiency and knowledge of Asian countries' labor market structures. Moreover, Hof asks attention for mobility capital - or what she calls after Kaufmann et al. (2004) "motility" - of her interlocutors, making her explore how they developed dispositions for migration and how they assess their early-career chances in European and Asian labor markets alike. More importantly even, for Hof such mobility capital is an effect of European or white privilege, enshrined in the value of an EU visa. The latter comes with the 'freedom' to leave Europe on a tourist visa, explore certain labor markets, and organize one's labor migration accordingly. Hof ends on a less triumphant tone, observing that “Europeans' migratory trajectories are a form of existential mobility, a moving out for moving faster than in Europe." While their European passports continue to benefit them in Asia, the young migrants operate in a larger set of constraints nevertheless. The latter manifest themselves in the different legal channels through which the young migrants enter their Asian destinations - as tourists or students, among others - and which entail an ambiguous legal status or unstable employment conditions at times.

Similarly, in the case spelled out by Heil the 'racial' privilege seems to have been collapsing as well. The recent Spanish newcomers in Rio often receive a precarious legal status, which excludes them from the formal labor markets they aspire to enter, and end up in the same stigmatized social category as that of African migrants. Yet, Heil observes irritation and resistance against what he calls this "colonial juxtaposition". Moreover, he notices his interlocutors' continuous access to the symbolic capital of whiteness linked to Brazil's colonial past and the reverberation of white supremacy and assumed civilizational superiority. For Heil it is clear that "whiteness and Europeanness" still count in the everyday encounters of his interlocutors in Rio de Janeiro in spite of the fact that the country had moved on away from the unquestioned hegemony of European whiteness.

Drawing even more explicitly on Bourdieu's work, Alloul coins the analytical term 'racial capital' in his research among well-trained Euro-Maghrebi, who move to the global city of Dubai in search of heretofore undreamed-of life chances. Alloul first explores forms of what he calls 'racial stuckedness': how the European emigrants apprehend the impossibility to valorize their educational capital in Europe as a direct outcome of racialization processes surrounding their Maghrebi background. In moving to Dubai, they seem on the contrary able to convert more successfully their 'racial capital', deriving from their phenotypical appearance, Maghrebi cultural repertoires, and European credentials. While their EU citizenship and educational capital grant 
access to honorary membership of the Western 'expat' group and its elite life style in Dubai, their 'Arab-Muslim' heritage facilitates social proximity to the native Emirati class, furthering their strategic positioning and overall career development. He thus concludes that translocal capital conversion, meaningful social distinction, and differential (im)mobility is also informed by powerful racial value configurations.

In his contribution about young Europeans with a Maghrebi background migrating to Montreal, Mandin makes similar movements as the ones made by Alloul. The kind of 'stuckedness' experienced is defined in terms of the impossibility of converting the cultural/educational capital one has acquired in Europe. In contrast, Montreal - with its distinctive dynamics of racialization of Maghrebi Muslim minorities - is experienced as a place with an alternative 'diversity regime' where such blockages are absent and allow for a more rewarding conversion of one's skills and 'identity'. The young professionals experience their move from Paris or Brussels to Montreal as a relocation away from the everyday oppression of being hyper-visible as someone with a Maghrebi background into an urban ambiance of indifference and openness in Canada. However, as much as the Spaniards in Rio (Heil) and the European youngsters in Singapore and Tokyo (Hof) try to make the most of the remnants of EU/white privilege, Mandin's Maghrebi interlocutors experience the growing reverberations of racial stigma emerging from Europe and the US and 'poisoning' Canadian public discourse, particularly on 'Muslims'.

Finally, Scharrer analyses how young Somalis are enabled by the cultural capital of their higher education in elite private schools in Kenya and later, in Europe, to stay in Europe with well-paid jobs - a confirmation of their membership of the upper-middle class in Kenya. This intersects with "the ambiguous position" of Somalis in Kenya: the fact that Somalis are both regarded as almost too successful migrants while not being able, however, to shed the stigma of terror suspects and refugees. To this ambiguity, the deeply ambivalent position of the global North as a high status zone is remarkable. For some Somali youngsters and their émigré parents, the labor done and the money earned in Europe appears to be valued higher than labor or money coming out of East Africa. This is not the case, however, for the independent business owners, whose money earned with their businesses in East Africa is regarded considerably higher as the money earned with lowly regarded jobs in Europe.

Taken together, starting from a conceptually broad take on 'crisis', pursuing people's migrations away from and through Europe, with the analytical help of Bourdieu's capital framework - adding novel types of 'capital' such as existential capital (Hof), racial capital (Alloul) in the process - these case studies bring out the full complexity of transnational socio-economic positioning. Above all the capital conversions give us a firmer grasp of the different conversion rates and regimes across the globe, not in the least, when intersected by 'race' and racialized ethnic or religious identities. Put simply, the global 'capital' transactions in which our interlocutors are involved are as much a matter of what is converted, as it is a question of who is converting where. The daunting background against which all these successful, failed or impossible transactions take place is that of a Europe in crisis -a hegemonic yet deeply contested source of global distinctions and stigmatizations.

\section{Acknowledgement:}


All of the papers in this special issue were presented at the conference Leaving Europe: alternative routes of out/upward mobility, which was held at KU Leuven on 13-14 September 2018. The conference was co-funded by the Research Foundation - Flanders (FWO) and the Doctoral School of Humanities \& Social Sciences (OJO financiering) at KU Leuven and grew out of the project Redefining "home": Transnational practices of European Muslims in Montréal and the United Arab Emirates (2014-2018) coordinated by Nadia Fadil and Karel Arnaut and funded by KU Leuven. In addition, part of this special issue's introduction was written in the framework of the ERC starting grant of Jean-Michel Lafleur Migration and transnational social protection in post-crisis Europe. Lastly, the authors wish to thank Dr Abdeslam Marfouk for his support with the quantitative data presented in this article.

\section{References:}

Anderson, Bridget. 2019. "New Directions in Migration Studies: Towards Methodological DeNationalism." Comparative Migration Studies 7(1):1-36. doi: 10.1186/s40878-019-0140-8.

Appadurai, Arjun. 1990. "Disjuncture and Difference in the Global Cultural Economy." Theory, Culture \& Society 7(2-3):295-310. doi: 10.1177/026327690007002017.

Bourdieu, Pierre. 1986. "The Forms of Capital." Pp. 241-58 in Handbook of Theory and Research for the Sociology of Education, edited by J. G. Richardson. Westport: Greenwood.

Brown, Wendy. 2006. Regulating Aversion. Tolerance in the Age of Identity and Empire. Princeton and Oxford: Princeton University Press.

Çağlar, Ayse. 2016. "Still 'Migrants' after All Those Years: Foundational Mobilities, Temporal Frames and Emplacement of Migrants." Journal of Ethnic and Migration Studies 42(6):95269. doi: 10.1080/1369183X.2015.1126085.

Çağlar, Ayşe and Nina Glick Schiller. 2018. "Migrants and City-Making: Dispossession, Displacement, and Urban Regeneration." Durham: Duke University Press.

Carruthers, Ashley. 2002. "The Accumulation of National Belonging in Transnational Fields: Ways of Being at Home in Vietnam." Identities 9(4):423-44. doi: 10.1080/10702890214872.

Chakrabarty, Dipesh. 2000. Provincializing Europe. Postcolonial Thought and Historical Difference. Princeton: Princeton University Press.

Cole, Jennifer. 2014. "Producing Value among Malagasy Marriage Migrants in France: Managing Horizons of Expectation." Current Anthropology 55(S9):S85-S94. doi: 10.1086/675928.

Dahinden, Janine. 2016. "A Plea for the 'De-Migranticization' of Research on Migration and Integration 1." Ethnic and Racial Studies 39(13):2207-25. doi: 10.1080/01419870.2015.1124129.

Dahrendorf, Ralf. 1980. Life Chances: Approaches to Social and Political Theory. Chicago: University of Chicago Press.

De Genova, Nicholas and Martina Tazzioli, eds. 2016. Europe / Crisis: New Keywords of "the Crisis" in and of "Europe". New York: Zone Books. (http://nearfuturesonline.org/europecrisisnew-keywords-of-crisis-in-and-of-europe/).

Erel, Umut. 2010. "Migrating Cultural Capital: Bourdieu in Migration Studies." Sociology 44(4):64260.

Fechter, Anne-Meike and Katie Walsh. 2010. "Examining 'Expatriate' Continuities: Postcolonial Approaches to Mobile Professionals." Journal of Ethnic and Migration Studies 36:1197-210. doi: $10.1080 / 13691831003687667$. 
Ferguson, James. 2005. "Decomposing Modernity: History and Hierarchy after Development." Pp. 166-81 in Postcolonial Studies and Beyond, edited by A. Loomba, et al. Durham: Duke University Press.

Fraser, Nancy. 2000. "Rethinking Recognition." New Left Review 3(May-June):107-20.

Glick Schiller, Nina and Noel B. Salazar. 2013. "Regimes of Mobility across the Globe." Journal of Ethnic and Migration Studies 39(2):183-200.

Gould, James D. 1979. "European Inter-Continental Emigration 1815-1914 : Patterns and Causes." The Journal of European economic history 8(3):593-679.

Green, Sarah. 2013. "Borders and the Relocation of Europe." Annual Review of Anthropology 42(1):345-61. doi: doi:10.1146/annurev-anthro-092412-155457.

Grillo, Ralph. 2010. "Contesting Diversity in Europe: Alternative Regimes and Moral Orders." MMG Working Paper 10-02.

Gsir, Sonia, Jean-Michel Lafleur and Mikolaj Stanek. 2016. "Migration Policy Reforms in the Context of Economic and Political Crises: The Case of Belgium." Journal of Ethnic and Migration Studies 42(10):1651-69.

Hage, Ghassan. 2003. Against Paranoid Nationalism: Searching for Hope in a Shrinking Society. Sydney: Pluto Press.

Hage, Ghassan. 2017. Is Racism an Environmental Threat? Cambridge: Polity.

Kaufmann, V., M.M. Bergman and D. Joye. 2004. "Motility: Mobility as Capital." International Journal of Urban and Regional Research 28(4):745-56.

King, Russell and Allan M. Williams. 2018. "Editorial Introduction: New European Youth Mobilities." Population, Space and Place 24(1):e2121. doi: 10.1002/psp.2121.

Krzyżanowski, Michał, Anna Triandafyllidou and Ruth Wodak. 2018. "The Mediatization and the Politicization of the 'Refugee Crisis' in Europe." Journal of Immigrant \& Refugee Studies 16(1-2):1-14.

Lafleur, Jean-Michel and Mikolaj Stanek, eds. 2017. South-North Migration of Eu Citizens in Times of Crisis. Cham: Springer International Publishing.

Luconi, Stefano. 2006. "Italians' Global Migration: A Diaspora? ." Studi Emigrazione 43(162):46782.

Mintz, Sidney W. 1998. "The Localization of Anthropological Practice: From Area Studies to Transnationalism." Critique of Anthropology 18(2):117-33. doi: 10.1177/0308275x9801800201.

Nieswand, Boris. 2006. "Methodological Transnationalism and the Paradox of Migration." Paper presented at the EASA Biennial Conference 2006, Bristol.

Nieswand, Boris. 2014. "The Burgers' Paradox: Migration and the Transnationalization of Social Inequality in Southern Ghana." Ethnography 15(4):403-25. doi: $10.1177 / 1466138113480575$.

Nowicka, Magdalena. 2013. "Positioning Strategies of Polish Entrepreneurs in Germany: Transnationalizing Bourdieu's Notion of Capital." International Sociology 28(1):29-47. doi: 10.1177/0268580912468919.

Oxley, Deborah. 1996. Convict Maids : The Forced Migration of Women to Australia. Cambridge: Cambridge University Press.

Papadopoulos, Dimitris and Vassilis S. Tsianos. 2013. "After Citizenship: Autonomy of Migration, Organisational Ontology and Mobile Commons." Citizenship Studies 17(2):178-96. doi: 10.1080/13621025.2013.780736.

Ramos, Cristina. 2018. "Onward Migration from Spain to London in Times of Crisis: The Importance of Life-Course Junctures in Secondary Migrations." Journal of Ethnic and Migration Studies 44(11):1841-57. doi: 10.1080/1369183X.2017.1368372. 
Reitz, Jeffrey. 1999. Warmth of the Welcome: The Social Causes of Economic Success in Different Nations and Cities. New York: Routledge.

Weiss, Anja. 2005. "The Transnationalization of Social Inequality: Conceptualizing Social Positions on a World Scale." Current Sociology 53(4):707-28. doi: 10.1177/0011392105052722.

\footnotetext{
${ }^{1}$ United Nations, Department of Economic and Social Affairs. Population Division (2017) Population Facts, No. 2017/5, URL: https://www.un.org/en/development/desa/population/publications/pdf/popfacts/PopFacts 2017-5.pdf
} 
Table 1. Number of international migrants from EU-28 Member States to non-European destination countries, 1990, 2005, 2019

\begin{tabular}{|l|l|l|l|}
\hline & $\begin{array}{l}\text { Total emigrant } \\
\text { population from } \\
\text { EU-28 }\end{array}$ & $\begin{array}{l}\text { EU-28 emigrants residing } \\
\text { outside of the European } \\
\text { continent }\end{array}$ & $\begin{array}{l}\text { EU-28 emigrants residing } \\
\text { outside of the European } \\
\text { continent in \% of total EU- } \\
28 \text { emigration }\end{array}$ \\
\hline 1990 & 24040374 & 12192497 & $51 \%$ \\
\hline 2005 & 28403205 & 11633745 & $41 \%$ \\
\hline 2019 & 36774353 & 12453683 & $34 \%$ \\
\hline
\end{tabular}

Source: UN population data and author's own elaboration.

Comment: To allow comparison between the year 1990, 2005 and 2019 we consider the same 28 countries even though they did not all join the EU at the same time. Consequently, emigrants from Austria, Bulgaria, Croatia, Cyprus, Czech Republic, Estonia, Finland, Hungary, Latvia, Lithuania, Malta, Poland, Romania, Slovakia, Slovenia, and Sweden are included in the emigration figures of 1990 and 2005 even though they were not all members of the UE at the time. In addition, in the two tables, we use the expression "outside of the European continent" to describe EU-28 emigrant population residing outside of the 44 countries listed as European in the European population data. 
Table 2. Number of international migrants from Germany, Spain, France, Italy and the UK to non-European destination countries, 1990, 2005, 2019

\begin{tabular}{|l|l|l|l|}
\hline & $\begin{array}{l}\text { Total emigrant } \\
\text { population from } \\
\text { DE, ES, FR, IT \& UK }\end{array}$ & $\begin{array}{l}\text { Total DE, ES, FR, IT \& UK } \\
\text { emigrants residing outside } \\
\text { the European continent }\end{array}$ & $\begin{array}{l}\text { Total DE, ES, FR, IT \& UK } \\
\text { emigrants residing outside } \\
\text { of the European continent } \\
\text { in of total emigration } \\
\text { from those countries }\end{array}$ \\
\hline 1990 & 12729701 & 7380443 & $58 \%$ \\
\hline 2005 & 13133845 & 6975493 & $53 \%$ \\
\hline 2019 & 15108454 & 7069716 & $47 \%$ \\
\hline
\end{tabular}

Source: UN population data and author's own elaboration. 